\title{
Increased Surface Expression of CD18 and CD11b in Leukocytes after Tourniquet Ischemia during Elective Hand Surgery
}

\author{
Paul M. Sutter, M.D., ${ }^{2,3}$ Giulio C. Spagnoli, M.D., ${ }^{2}$ Axel Marx, M.D., ${ }^{2,3}$ Lorenz Gürke, M.D., ${ }^{1}$ Hans Troeger, M.D., ${ }^{1}$ \\ Renato Fricker, M.D., ${ }^{1}$ Felix Harder, M.D., ${ }^{1}$ Michael Heberer, M.D. ${ }^{2}$ \\ 'Department of Surgery, Kantonsspital Basel, Spitalstrasse 21, 4031 Basel, Switzerland \\ ${ }^{2}$ Department of Surgical Research, Kantonsspital Basel, 4031 Basel, Switzerland \\ ${ }^{3}$ Department of Surgery, Ospedale Civico Lugano, Via Tesserete 46, 6900 Lugano, Switzerland
}

\begin{abstract}
The surface expression of $\beta_{2}$-integrins was investigated in leukocytes from patients undergoing ischemia induced by tourniquet application for elective hand surgery. Blood samples were obtained before initiation, at the end of ischemia, and after 15 minutes of reperfusion from ischemic and contralateral arms of five patients. Comparable expression of CD18, CD11a, CD11b, and CD11c could be detected by immunofluorescence in leukocytes from samples drawn from either arm before tourniquet application. In contrast, a significant increase in the expression of $\mathrm{CD} 18$ was detectable in monocytes, granulocytes, and lymphocytes from the ischemic arm compared with that in the nonischemic contralateral control, at the end of the ischemia time $(80 \pm 16$ minutes). A significantly increased expression of CD11b, but not CD11a or CD11c, determinants was also observed in granulocytes and monocytes. Concomitantly, a significant reduction in the percentages of granulocytes in samples from ischemic areas was detectable. After 15 minutes of reperfusion, differences in the expression of these adhesion molecules were no longer significant. The expression of the genes encoding interleukins IL-1 $\alpha$, IL-1 $\beta$, and IL-6 and tumor necrosis factor alpha (TNF $\alpha$ ) proinflammatory cytokines was also studied by reverse polymerase chain reaction (rPCR) in peripheral blood mononuclear cells (PBMCs) obtained from the same samples in three patients. IL-1 $\beta$ or IL-6 gene expression was never observed. Expression of IL-1 $\alpha$ and TNF $\alpha$ genes, as detected in two patients, was not related with induction of ischemia. However, in these patients expression of one or both these genes was observed in samples derived from the ischemic but not the control arm after 15 minutes of reperfusion. These data document that overexpression of adhesion molecules and sequestration of leukocytes take place following short ischemia times, as routinely applied clinically for minor surgical procedures.
\end{abstract}

Ischemia/reperfusion injury represents a potential complication of vascular injury, trauma, and transplantation surgery. Activation of leukocytes, endothelium, or both leading to increased cell adhesion and extravasation can result in damage of the vessel walls and surrounding tissues, particularly during the reperfusion phase. Furthermore, cytokines and other mediators can be produced, possibly responsible for distant effects targeting the liver and the pulmonary capillary area $[1,2]$.

Experimental models have addressed in detail the molecular bases of ischemia reperfusion damage. Leukocyte infiltration, as

Correspondence to: P.M. Sutter, M.D., Surgical Research Laboratory, Z.L.F., 20 Hebelstrasse, 4031 Basel, Switzerland detectable in postischemic tissues, appears to largely mediate injury induction. Indeed, leukocyte depletion has been shown to decrease the severity of reperfusion damage, and monoclonal antibodies (mAbs) specific for CD18 protect tissues from postischemic injury [3-8].

Clinically, tourniquet-induced ischemia is routinely applied during limb surgery to ensure a relatively bloodless operative field. If prolonged in time, it may lead to skeletal muscle damage and impaired postoperative function [9-11]. However, clinical data concerning the activation of adhesion molecules in leukocytes during ischemia and reperfusion are sparse to date.

In this work we took advantage of tourniquet application in elective hand surgery to investigate the surface expression of $\beta_{2}$-integrins in different leukocyte populations under ischemic and postischemic conditions. Concomitantly, the induction of proinflammatory cytokines' gene expression was assayed by the reverse polymerase chain reaction (rPCR).

We report here that a significant increase in the expression of Mac-1 (CD11b/CD18) $\beta_{2}$-integrin is detectable in granulocytes and monocytes from arms undergoing relatively short (60-101 minutes) ischemia times. Under these conditions, proinflammatory cytokines do not appear to play a role the induction of these events.

\section{Patients and Methods}

\section{Experimental Design}

Five patients undergoing elective hand surgery (Table 1) in the absence of systemic diseases were studied. All patients except one were anesthetized with regional brachial block anesthesia. No Esmarch bandage exsanguination was applied. Heparinized venous blood samples were obtained from both arms before initiation of surgery but after induction of anesthesia in the limb undergoing surgery. Subsequently, a tourniquet was applied on the upper arm at a pressure of $300 \mathrm{mmHg}$. Duration of ischemia ranged between 60 and 101 minutes ( $80 \pm 16$ minutes). At the end of surgery and immediately before releasing the tourniquet, a 
Table 1. Patient characteristics.

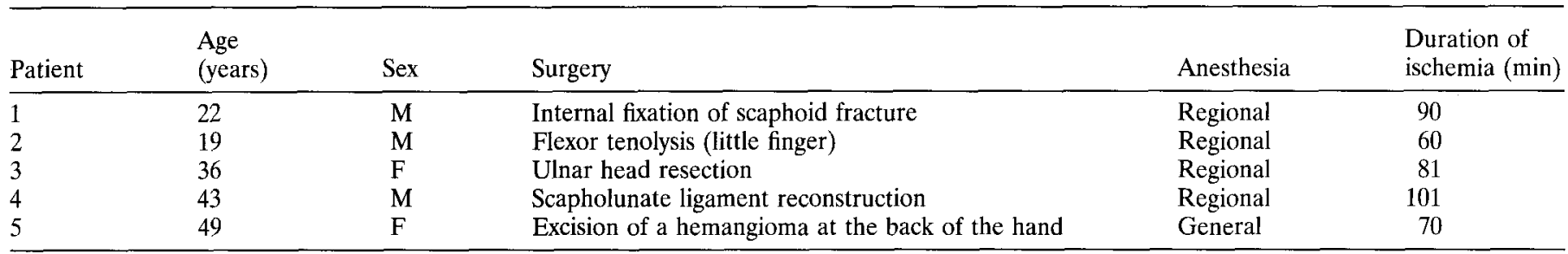

Table 2. Pairs of primers used in this study.

\begin{tabular}{lll}
\hline Gene & Sequence & Size $^{a}$ \\
\hline$\beta$-Actin & Sense: TGACGGGGTCACCCACACTGTGCCCATCTA & 661 \\
IL-1 $\alpha$ & Antisense: CTAGAAGCATTGCGGTGGACGATGGAGGG \\
& Sense: ATGGCCAAAGTCCAGACATGTTTG \\
IL-1 $\beta$ & Antisense: GGTTTCCAGTATCTGAAAGTCAGT \\
& Sense: CTTCATCTTTTGAAGAAGAACCTATCTTCTT \\
IL-6 & Antisense: AATTTTGGGATCTACACTCTCCAGCTGTA \\
& Sense: ATGAACTCCTTCTCCACAAGCGC \\
TNF $\alpha$ & Antisense: GAAGAGCCCTCAGGCTGGACTG \\
& Sense: ATGAGCACTGAAAGCATGATCCGG \\
& Antisense: GCAATGATCCCAAAGTAGACCTGCCC \\
\hline
\end{tabular}

${ }^{a}$ Expected size of the amplified fragment expressed as number of basepairs.

second blood sample was obtained from both arms. A third sample was obtained from both limbs 15 minutes after the termination of ischemia. In some experiments another blood specimen was obtained 1 minute after release of the tourniquet.

\section{Phenotypic Studies}

Phenotypic studies were performed on whole blood to avoid separation procedures likely to affect the expression of adhesion molecules [12]. Briefly, $50 \mu 1$ of heparinized venous blood were incubated in the presence of fluorochrome-labeled mAbs recognizing CD14, CD45, CD11b (Becton-Dickinson, San Jose, CA, USA). The mAbs directed against CD11a, CD11c, CD18, and CD54 (ICAM-1) were obtained from Serotec (Oxford, UK). Erythrocytes were lysed (FACS lysis buffer, Becton-Dickinson) after 15 minutes of incubation at room temperature. Following two washes, cells were resuspended in phosphate-buffered saline (PBS) $0.2 \%$ paraformaldehyde, and specific fluorescence was quantitatively evaluated on a FACScan fluorocytometer equipped with Lysis II software (Becton-Dickinson). The instrument's settings were adjusted by taking advantage of CaliBRITE beads and AutoComp software (both from Becton-Dickinson). Student's $t$-test for paired samples was used in the statistical analysis of data throughout this study.

\section{PCR Studies}

Peripheral blood mononuclear cells were obtained from heparinized venous blood samples by centrifugation on density gradients (Lymphoprep; Nycomed, Oslo, Norway). Total cellular RNA was extracted and reverse-transcribed as described previously [13]. The cDNA thus obtained was assayed in 35-cycle PCR reactions in the presence of pairs of primers specific for $\beta$-actin housekeeping gene as the positive control and interleukins IL- $1 \alpha$, IL-1 $\beta$, and IL- 6 and tumor necrosis factor alpha (TNF $\alpha$ ) genes (Table 2). PCR products were then electrophoresed in the presence of ethidium bromide on agarose gels that were subsequently photographed under ultraviolet (UV) transillumination. The specificity of the amplified genes was validated by restriction mapping [13].

\section{Results}

\section{Effects of Ischemia on Leukocyte Populations}

Absolute counts of leukocytes did not significantly differ in blood samples drawn from the ischemic or the control arm at any of the time points under investigation (data not shown). Percentages of granulocytes, monocytes, and lymphocytes in blood samples were evaluated by taking advantage of physical cytometric parameters [forward scatter (FSC) and side scatter (SSC)] and phenotypic characteristics. Monocytes are $\mathrm{CD} 14^{+} / \mathrm{CD} 45^{+}$cells, whereas lymphocytes are $\mathrm{CD} 14^{-} / \mathrm{CD} 45$ bright cells and granulocytes appear as CD $14^{-} / \mathrm{CD} 45$ dim cells. No differences in the relative percentages of granulocytes, monocytes, and lymphocytes were observed in samples drawn from either limb before ischemia. In contrast, at the end of ischemia, as reported in Figure 1, a significant decrease of the granulocytes' percentages could be observed in samples obtained from the ischemic arm $(57.7 \pm 9.7 \%)$ compared with values simultaneously obtained from the nonischemic limb $(71.1 \pm 9.5 \%)$. In parallel, increased lymphocytes' percentages were detected in the same specimens $(38.2 \pm 9.1 \%$ versus $24.2 \pm$ $8.6 \%$ ). No significant modifications of the monocytes' percentages were detectable under these conditions. After 15 minutes of 


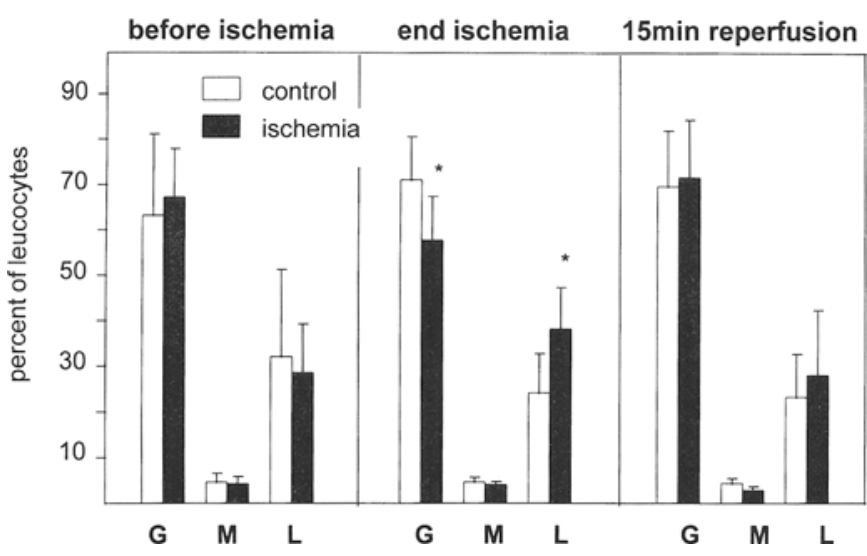

Fig. 1. Differential percentages of leukocytes. Percentages of granulocytes, monocytes, and lymphocytes in blood samples from ischemic and nonischemic areas. Heparinized blood was obtained at the indicated times from ischemic limbs (shaded columns) and control limbs (open columns). The percentages of granulocytes (G), monocytes (M), and lymphocytes (L) among the total leukocytes were evaluated by staining with fluorochrome-labeled anti-CD14 and anti-CD45 mAbs. Data from the five patients under investigation are reported as mean values \pm standard deviations. Asterisks indicate significant differences $(p<0.05)$. For other details see Materials and Methods.

reperfusion, comparable percentages of granulocytes, monocytes, or lymphocytes were observed in samples obtained from the two limbs (Fig, 1).

\section{CD18 Expression in Leukocytes from Ischemic Areas}

Surface expression of $\mathrm{CD} 18$ was quantitatively evaluated in granulocytes, monocytes, and lymphocytes from ischemic and nonischemic arms before application of the tourniquet, at the end of ischemia, and after 15 minutes of reperfusion. As shown in Figure 2, CD18 expression in leukocyte populations was comparable in samples obtained from the two arms before ischemia (206.8 \pm 72.2 versus $174.0 \pm 42.8$ for granulocytes, $387.4 \pm 156.8$ versus $349.2 \pm 95.7$ for monocytes, $239.4 \pm 42.5$ versus $243.8 \pm$ 23.1 for lymphocytes). A significant increase of CD18 expression concerning all leukocyte populations was detected in samples derived from the ischemic arm at the end of ischemia compared with those obtained from the contralateral limb $(321.2 \pm 50.2$ versus $188.8 \pm 37.5$ for granulocytes, $653 \pm 54.4$ versus $426.0 \pm$ 121.6 for monocytes, $299.0 \pm 44.5$ versus $228.2 \pm 36.0$ for lymphocytes). After 15 minutes of reperfusion, regarding granulocytes and monocytes, apparent differences in the expression of CD18 in samples obtained from the ischemic arm compared with the untreated arm (331.4 \pm 72.5 versus $234.8 \pm 66.9$ for granulocytes, $567.4 \pm 157.4$ versus $443.2 \pm 120.8$ for monocytes) were no longer significant. Regarding lymphocytes, virtually identical values were observed in cells from the two arms $(222.2 \pm 48.7$ versus $220.0 \pm 56.9$ ).

\section{Effects of Ischemia on Expression of $\alpha$-Chains of $\beta_{2}$-Integrins on Leukocyte Surfaces}

Because ischemia appeared to increase surface expression of $\mathrm{CD} 18$, the common $\beta$-chain of $\beta_{2}$-integrins, the expression of

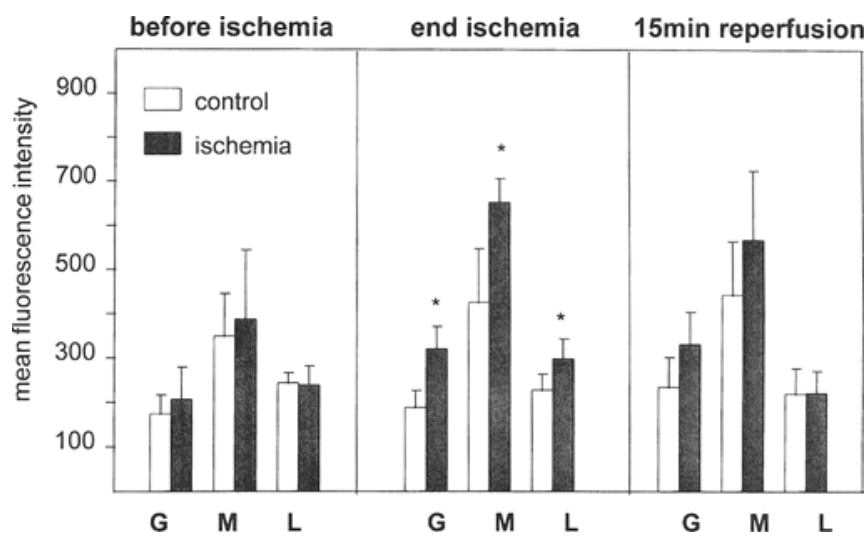

Fig. 2. Surface expression of CD18 in leukocytes from ischemic and nonischemic areas. Expression of CD18 was evaluated quantitatively, as the mean fluorescence intensity, in granulocytes $(G)$, monocytes $(M)$, and lymphocytes $(\mathrm{L})$ from blood samples obtained at the indicated times from ischemic arms (shaded columns) and nonischemic arms (open columns). Data from the five patients, expressed in arbitrary units, are reported as mean values \pm standard deviations. Asterisks indicate significant differences $(p<0.05)$. For other details see Materials and Methods.

$\alpha$-chains was also investigated. As shown in Figure 3, CD11b expression before ischemia was comparable in leukocyte populations in samples from either arm. In contrast, CD11b expression was significantly increased in granulocytes $(499.8 \pm 341.7$ versus $213.0 \pm 149.8)$ and monocytes $(532.8 \pm 358.6$ versus $237.3 \pm$ 205.9) from the ischemic arm compared with cells derived from the contralateral limb at the end of ischemia. At close resemblance to CD18, apparent differences detectable after 15 minutes of reperfusion $(474.4 \pm 281.7$ versus $284.6 \pm 214.4$ for granulocytes and $531.8 \pm 358.1$ versus $345 \pm 291.8$ for monocytes) were no longer significant. On the other hand, no modifications of CD11b expression were observed on lymphocyte surfaces at any of the times considered. Remarkably, no significant differences in the expression of CD11a and CD11c were detectable in leukocyte populations at any time (data not shown).

\section{ICAM-1/CD54 Expression in Leukocytes from Ischemic or Nonischemic Areas}

Because ICAM-1/CD54 represents a major ligand molecule for CD11a and CD11b integrins, its expression was analyzed in leukocytes from ischemic and nonischemic limbs. At a striking difference with $\mathrm{CD} 18$, no significant variation in the surface expression of ICAM-1/CD54 could be detected in granulocytes, monocytes, or lymphocytes following ischemia compared to the expression in cells from the nonischemic limb (data not shown).

\section{Cytokine Gene Expression in Mononuclear Cells from Ischemic or Nonischemic Areas}

Expression of IL-1 $\alpha$, IL-1 $\beta$, IL-6, and TNF $\alpha$ genes was investigated by 35 -cycle rPCR in RNA from peripheral blood mononuclear cells (PBMCs) obtained simultaneously with the samples used for phenotypic studies. Three patients were studied. The 


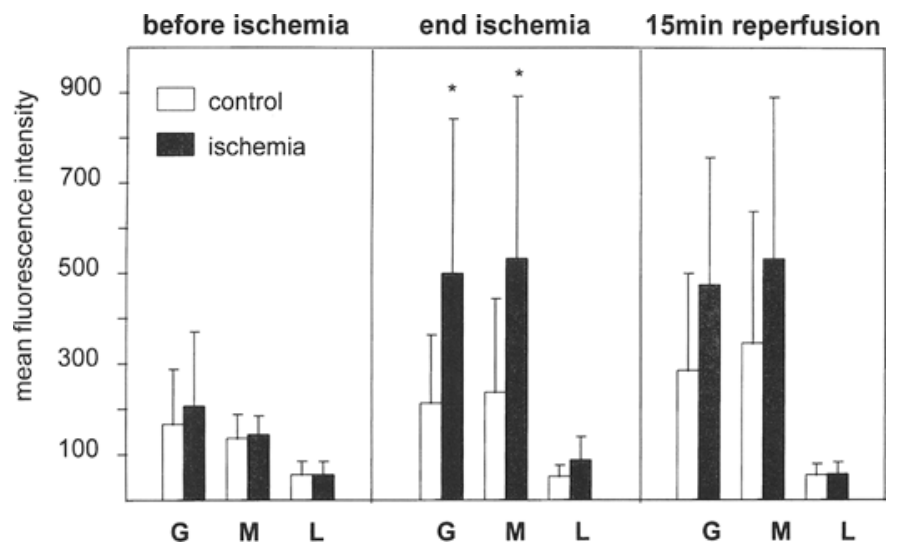

Fig. 3. Surface expression of CD11b in leukocytes from ischemic and nonischemic areas. Expression of CD11b was evaluated quantitatively, as the mean fluorescence intensity, in granulocytes $(\mathrm{G})$, monocytes $(\mathrm{M})$, and lymphocytes (L) from blood samples obtained at the indicated times from ischemic arms (shaded columns) and nonischemic arms (open columns). Data from the five patients, expressed in arbitrary units, are reported as means \pm standard deviations. Asterisks indicate significant differences $(p<0.05)$. For other details see Materials and Methods.

$\beta$-actin housekeeping gene was expressed in all samples, testifying to the integrity of the test system. IL- $1 \beta$ and IL- 6 transcripts could not be detected in any of the samples under investigation. In patient 1, IL- $1 \alpha$ gene expression was barely detectable in preischemia samples. On the other hand, this gene was found to be relatively highly expressed in samples from both ischemic and control arms at the end of ischemia and after 1 minute of reperfusion as well as in PBMCs from the ischemic limb only after 15 minutes of reperfusion. In contrast, no expression could be observed in the 15-minute reperfusion sample from the nonischemic control arm (Fig. 4, Table 3). Regarding TNF $\alpha$ gene, in this patient weak expression was observed in all samples, with the exception of PBMCs obtained after 15 minutes of reperfusion from the control arm. Interestingly, TNF $\alpha$ expression was also detectable in PBMCs from patient 3 obtained from the ischemic arm after 15 minutes of reperfusion (Table 3).

\section{Discussion}

The mechanisms underlying ischemia/reperfusion-associated injury have been thoroughly investigated in a number of experimental models [14, 15]. Emerging evidence concordantly attributes a key role to leukocytes in the generation of postischemic damage. Overexpression of adhesion molecules and production of proinflammatory cytokines would lead to leukocyte infiltration of postischemic tissues, a key step in the induction of reperfusion injury [16]. Furthermore, leukocyte-endothelial cell adhesion is thought to create a microenvironment favoring the release of toxic products, including reactive oxidant metabolites [17]. In this context, evidence that administration of CD18-specific mAbs can prevent generation of mucosal damage following intestinal ischemia [7-9] suggests a major relevance of these molecules in the induction of ischemia/reperfusion-related injury.

Despite myriad experimental data, however, little information is available on these events as detectable in clinical situations. Significant neutropenia and reduction of the percentages of granulocytes expressing $\mathrm{CD} 11 \mathrm{~b} / \mathrm{CD} 18$ and $\mathrm{CD} 11 \mathrm{c} / \mathrm{CD} 18$ was ob-
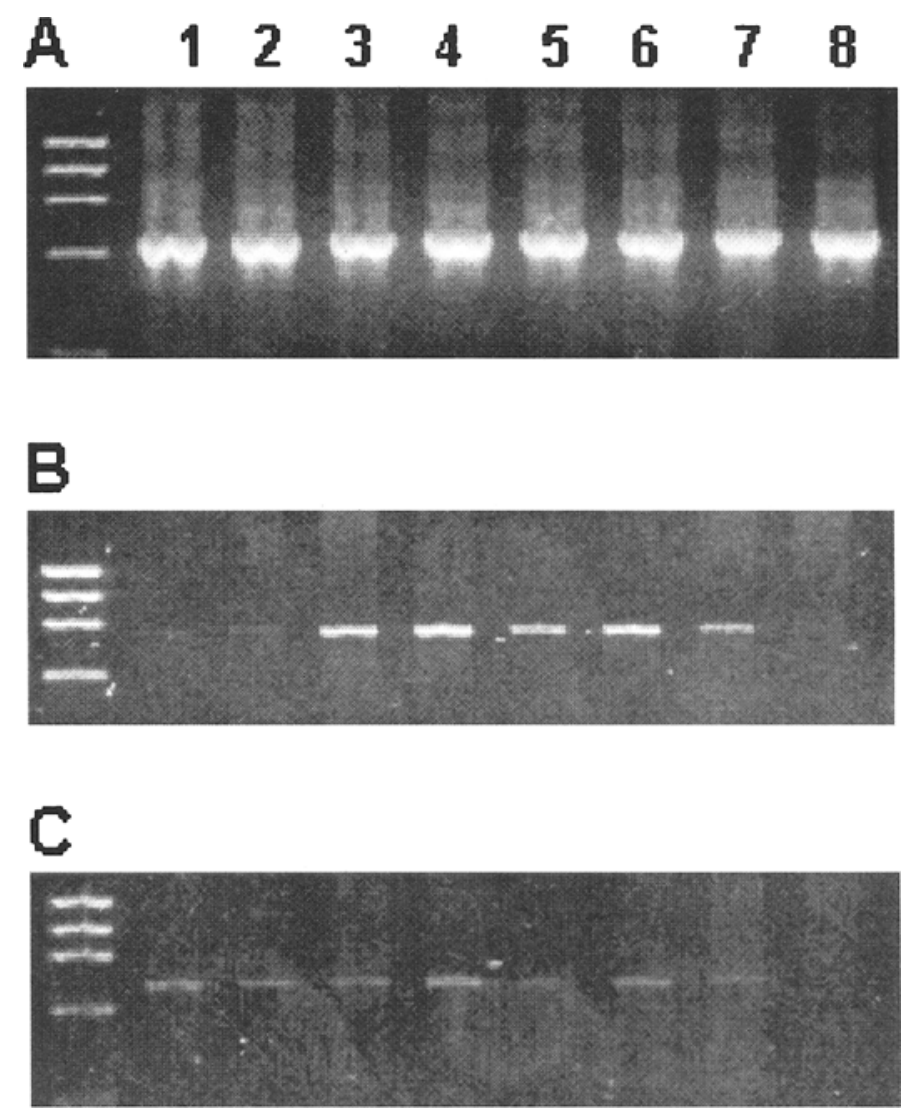

Fig. 4. Cytokine gene expression in peripheral blood mononuclear cells (PBMCs) from ischemic and nonischemic areas. Total cellular RNA was extracted from Ficoll-purified PBMCs and reverse-transcribed. The cDNA thus obtained was amplified by 35-cycle PCR in the presence of primers specific for $\beta$-actin (A), IL- $1 \alpha$ (B), and TNF- $\alpha(\mathbf{C})$. PCR products were electrophoresed in the presence of ethidium bromide and photographed under UV transillumination. Samples were obtained before initiation of ischemia (lanes 1 and 2), at the end of ischemia (lanes 3 and 4 ), after 1 minute of reperfusion (lanes 5 and 6 ), and after 15 minutes of reperfusion (lanes 7 and 8 ). Lanes $1,3,5$, and 7 contain samples from the ischemic arm, whereas lanes $2,4,6$, and 8 contain samples from the contralateral arm. For other details see Materials and Methods.

served in patients affected by peripheral arterial occlusive disease following physical exercise [18].

In this work we analyzed the expression of $\beta_{2}$-integrins in a group of patients undergoing elective hand surgery, implying application of a tourniquet and an ischemia time ranging between 60 and 101 minutes. Differently from most experimental models, however, we specifically addressed the expression of adhesion molecules at the end of ischemia and after a short (15-minute) reperfusion.

In keeping with observations in animal models, we found that relatively short ischemia times, as required for technical reasons during minor surgical procedures, induce overexpression of CD18 on the surface of granulocytes, monocytes, and lymphocytes. In parallel, a concomitant, significant increase in the expression of CD11b, but not CD11a or CD11c, is detectable on granulocytes and monocytes. Local sequestration of granulocytes was also observed, as witnessed by their decreased percentages in effluent blood. Considering the relatively rapid kinetics of these phenomena, translocation of adhesion molecules from intracellular gran- 
Table 3. Expression of proinflammatory cytokine genes in PBMCs from ischemic and nonischemic areas.

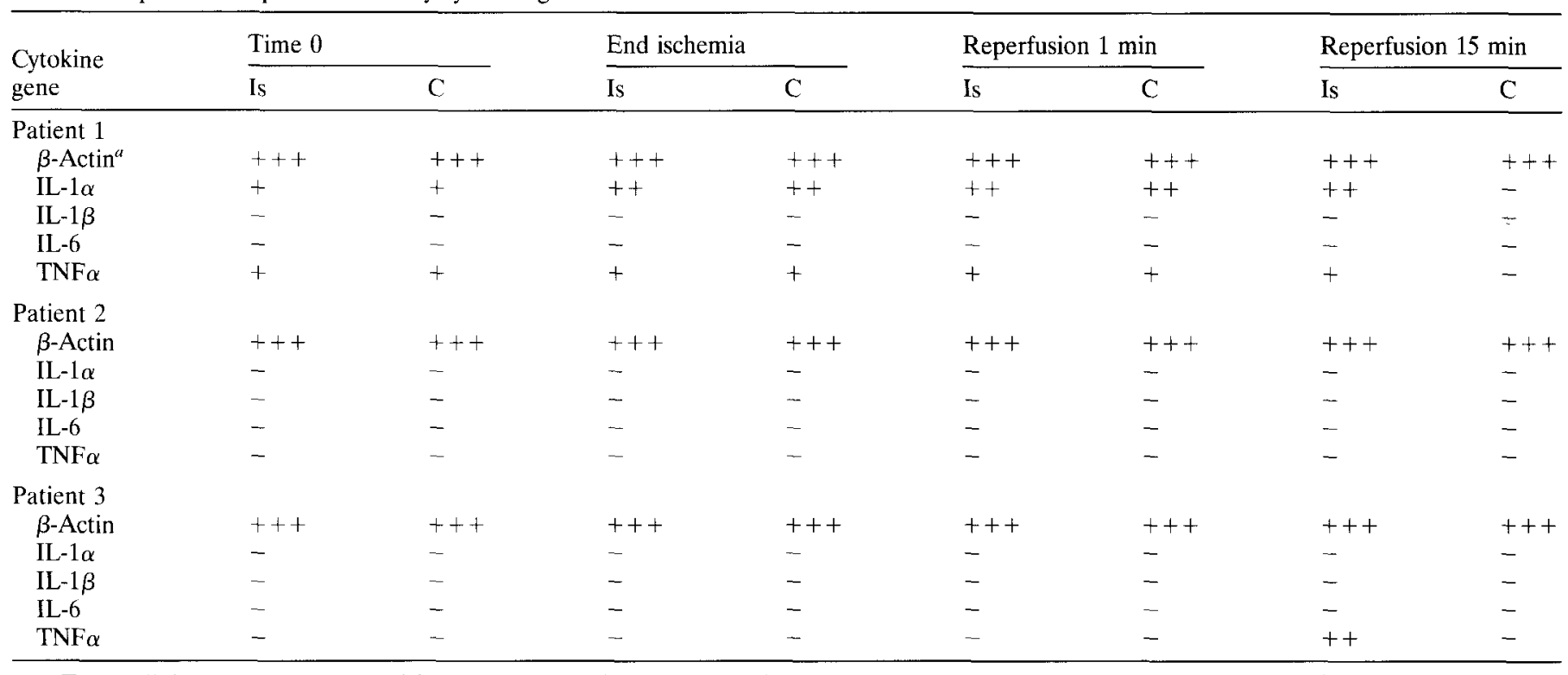

Total cellular RNA was extracted from PBMCs obtained from blood samples drawn at the indicated times from ischemic (Is) or contralateral (C) arms and reverse-transcribed.

${ }^{a}$ CDNA was assayed during 35-cycle PCR in the presence of the appropriate pairs of primers (see Table 2). Amplification products were run on agarose gels in the presence of ethidium bromide and photographed under UV transillumination.

-: no detectable PCR product; +-+++ : intensity (in arbitrary units) of the fluorescence emitted by amplified genes under investigation following electrophoresis in the presence of ethidium bromide (see also Fig. 4).

ules to the cell surfaces, as observed in experimental models [19], is highly likely.

Granulocytes and monocytes obtained from the ischemic arm after 15 minutes of reperfusion still display an apparently higher expression of $\mathrm{CD} 18$ and $\mathrm{CD} 11 \mathrm{~b}$ than did their counterparts sampled simultaneously from the nonischemic limb. These differences, however, are no longer significant. This could be related to the "dilution" of the blood from the ischemic area into the systemic circulation.

It has been suggested that cytokine production by leukocytes trapped in ischemic areas might activate both leukocytes and endothelial cells, resulting in the overexpression of adhesion molecules and their ligands [20]. White blood cell sequestration would ensue. Our data on cytokine gene expression in PBMCs do not support this hypothesis. In fact, no IL- $1 \beta$ or IL-6 transcripts could be amplified. As for IL- $1 \alpha$ and TNF $\alpha$ genes, in two of three patients no expression was detectable in mononuclear cells from the ischemic arm at the end of ischemia. Furthermore, expression of these genes in patient 1 did not appear to be directly related to the ischemia inasmuch as it was also observed in samples from the contralateral, nonischemic arm. Clearly, we cannot exclude that other relevant cytokines, possibly produced by other cell types, might be involved.

It is worth noting, however, that in two of three patients we observed a discrepancy in cytokine gene expression in PBMCs from blood sampled from the two arms after 15 minutes of reperfusion. Based on these data and taking into account the high sensitivity of rPCR, it is tempting to speculate that activated cells, expressing cytokine genes, could be sequestered in the ischemic areas following adhesion to activated endothelial cells and slowly released in the systemic blood flow.

Taken together, our data document that after routine minor surgical procedures, usually devoid of significant postsurgery complications, molecular events typically involved in the generation of postischemic damage are observed.

\section{Résumé}

L'expression de surface des intégrins $\beta_{2}$ des leucocytes a été analyséc chez les patients opérés de la main ayant une ischémie induite par un garrot appliqué au niveau du bras. On a prélevé du sang aux deux bras, chez cinq patients, avant et 15 minutes après l'ischémie provoquée. Par immunofluorescence on a mis en évidence l'expression des intégrins CD18, CD11a, CD11b et CD11c. L'expression avant l'ischémie était comparable dans les deux bras. Par contre, on a retrouvé à la fin de l'ischémie provoquée $(80 \pm 16$ minutes) une augmentation significative de l'expression de CD18 dans les monocytes, les polynucléaires et les lymphocytes du bras sous garrot, comparé au bras libre contrôle. On a également retrouvé une augmentation de l'expression de CD11b, mais pas de CD11a ou de CD11c, dans les polynucléaires et les monocytes. Dans le même temps, on a détecté une réduction significative du pourcentage des polynucléaires dans les zones ischémiques. Après 15 minutes de reperfusion, les différences dans l'expression de ces molécules d'adhésion n'étaient plus significatives. L'expression des gènes qui codent les cytokines proinflammatoires IL-1- $\alpha$, IL-1 $\beta$, IL- 6 and TNF- $\alpha$ a été également étudiée par une réaction en chaîne de polymérase inversée dans les cellules mononucléées du sang périphérique (PBMC) obtenues à partir de ces mêmes échantillons chez trois patients. L'expression des gènes IL-1 $\beta$ ou IL-6 n'a jamais été observée. L'expression des gènes IL- $1 \alpha$ et TNF- $\alpha$, détectéc chez deux patients, n'était pas en rapport avec l'ischémie. Après 15 minutes de reperfusion, l'expression d'un ou des deux gènes pouvaient être détectée dans les échantillons provenant du bras ischémié mais pas dans le bras contrôle. Ces données confirment que la surexpression des molécules d'adhésion et la séquestration des leuco- 
cytes ont lieu après des temps d'ischémie relativement courts, tels que ceux qui sont entraînés par les procédés chirurgicaux mineurs de tous les jours.

\section{Resumen}

Se investigó la expresión de superficie de las integrinas-b2 en leucocitos de pacientes sometidos a isquemia por aplicación de un torniquete para cirugía electiva de la mano. En 5 pacientes se tomaron muestras de sangre antes de la iniciación y al final de la isquemia y luego de 15 minutos de reperfusión de la isquemia y en el brazo contralateral. Se detectó expresión comparable de CD18, CD11a, CD11b y CD11c mediante immunofluorescencia en leucocitos de las muestras tomadas de cualquiera de los dos brazos antes de la aplicación del torniquete. En contraste, se detectó un incremento significativo de la expresión de CD18 en monocitos, granulocitos y linfocitos del brazo isquémico, en comparación con el control contralateral no isquémico, al final del período de isquemia ( $80 \mathrm{~B} 116$ minutos). También se observó una expresión significativamente aumentada de CD11b, pero no de determinantes de CD11a o CD11c, en granulocitos y monocitos. En forma concomitante, se detectó una reducción significativa en el porcentaje de granulocitos en muestras de territorios isquémicos. Luego de 15 minutos de reperfusión, la diferencia en la expresión de éstas moléculas de adhesión dejó de ser significativa. La expresión de los genes, que encodan la citocinas proinflamatorias IL-1E0, IL-1á, IL-6 y FNT-E0 también fue estudiada por medio de la técnica de rPCR en células sanguíneas mononucleares periféricas obtenidas a partir de las mismas muestras, en tres pacientes. No se observó expresión del gen IL-1á o IL-6. La expresión de los genes de IL-1E0 y FNT-E0, según fue detectada en dos pacientes, no se relacionó con la inducción de isquemia. Sin embargo, en estos pacientes la expresión de uno o de los dos genes pudo ser observada en muestras derivadas del brazo isquémico pero no en las del brazo control, despuaés de 15 minutos de reperfusión. Estos datos documentan que la sobre-expresión de moléculas de adhesión y el secuestro de leucocitos tienen lugar luego de cortos tiempos de isquemia, tales como se aplican en el curso de procedimientos quirúrgicos menores.

\section{Acknowledgments}

This work was partially supported by a grant from the Swiss National Science Foundation (grant 3200-043639.95/1 to L.G.). The expert technical assistance of Ms. Bianca Giesen is gratefully acknowledged.

\section{References}

1. Welbourn, C.R.B., Goldman, G., Paterson, I.S., Valeri, C.R., Shepro, D., Hectman, H.B.: Pathophysiology of ischemia-reperfusion injury: central role of the neutrophil. Br. J. Surg. 78:651, 1991
2. Grace, P.A.: Ischaemia-reperfusion injury. Br. J. Surg. 81:637, 1994

3. Barroso-Aranda, J., Schmid-Schonbein, G.W., Ifach, B.W., Engler, R.L.: Granulocytes and no-reflow in irreversible hemorragic shock. Circ. Res. 63:437, 1988

4. Korthuis, R.J., Grisham, M.B., Granger, D.N.: Leukocyte depletion attenuates vascular injury in postischemic skeletal muscle. Am. J. Physiol. 254:H823, 1988

5. Carden, D.L., Smith, J.K., Korthuis, R.J.: Neutrophil mediated microvascular dysfunction in postischemic canine skeletal muscle. Circ. Res. 66:1436, 1990

6. Vedder, N.B., Winn, R.K., Rice, C.L., Chi, E.Y., Arfors, K.E., Harlan, J.M.: A monoclonal antibody to adherence promoting leukocyte glycoprotein, CD18; reduces organ injury and improves survival from hemorrhagic shock and resuscitation in rabbits. J. Clin. Invest. 81:939, 1988

7. Ma, X.L., Tsao, P.S., Lefer, A.M.: Antibody to CD18 exerts endothelial and cardiac protective effects in myocardial ischemia and reperfusion. J. Clin. Invest. 88:1237, 1991

8. Simpson, P.J., Todd, R.F., Fantone, J.C., Mickelson, J.K., Griffin, J.D., Lucchesi, B.R.: Reduction of experimental canine myocardial reperfusion injury by a monoclonal antibody (anti-Mo 1, anti CD11b) that inhibits leucocyte adhesion. J. Clin. Invest. 81:624, 1988

9. Petrasek, P.F., Liauw, S., Romaschin, A.D., Walker, P.M.: Salvage of postischemic skeletal muscle by monoclonal antibody blockage of neutrophil adhesion molecule CD18. J. Surg. Res. 56:5, 1994

10. Silver, R., De La Garza, J., Rang, M., Koreska, J.: Limb swelling after release of a tourniquet. Clin. Orthop. 206:86, 1986

11. Salam, A.A., Eyres, K.S., Cleary, J., El-Sayed, H.H.: The use of a tourniquet when plating tibial fractures. J. Bone Joint Surg. [Br.] 73:86, 1991

12. Macey, M.C., McCarty, D.A., Vordermeyer, S., Newland, A.C., Brown, K.A.: Effects of cell purification methods on CD11b and $\mathrm{L}$-selectin expression as well as the adherence and activation of leucocytes. J. Immunol. Methods 181:211, 1995

13. Lüscher, U., Filgueira, L., Juretic, A., Zuber, M., Lúscher, N.J., Heberer, M., Spagnioli, G.C.: The pattern of cytokine gene expression in freshly excised human metastatic melanoma suggests a state of reversible anergy of tumor-infiltrating lymphocytes. Int. J. Cancer $57: 612,1994$

14. Hernandez, L.A., Grisham, M.B., Twohig, B., Arfors, K.E., Harlan, J.M., Granger, D.N.: Role of neutrophils in ischemia reperfusion induced microvascular injury. Am. J. Physiol. 253:H699, 1987

15. Farb, A., Kolodgie, F.D., Jenkins, M., Virmani, R.: Myocardial infarct extension during reperfusion after coronary artery occlusion: pathologic evidence. J. Am. Coll. Cardiol. 21:2145, 1993

16. Vollmar, B., Menger, M.D., Glasz, J., Leiderer, R., Messmer, K.: Impact of leucocyte-endothelial cell interaction in hepatic ischemia reperfusion injury. Am. J. Physiol. 267:G786, 1994

17. Smith, J.K., Grisham, M.B., Granger, D.N., Korthuis, R.I.: Free radical defense mechanisms and neutrophil infiltration in postischemic skeletal muscle. Am. J. Physiol. 256:H789, 1989

18. Ciuffetti, G., Lombardini, R., Paltriccia, R., Santambrogio, L., Mannarino, E.: Human leucocyte-endothelial interactions in peripheral arterial occlusive disease. Eur. J. Clin. Invest. 24:65, 1994

19. Zimmermann, G.A., Prescott, S.M., McIntyre, T.M.: Endothelial cell interactions with granulocytes: tethering and signaling molecules. Immunol. Today 13:93, 1992

20. Ascer, E., Gennaro, M., Cupo, S., Mohan, C.: Do cytokines play a role in skeletal muscle ischemia and reperfusion? J. Cardiovasc. Surg. 33:588, 1992 